\title{
Hepatitis E virus seroprevalence in haemodialysis patients in Zanjan province, Islamic Republic of Iran
}

\author{
A. R. Mobaien, ${ }^{7}$ R. Mohammadi, ${ }^{2}$ R. Sorouri ${ }^{3}$ and K. Sadeghi ${ }^{4}$
}

$$
\begin{aligned}
& \text { معدّل الانتشار المصلي لفيروس التهاب الكبد "ئي" بين مرضى الديال في زنجان، في جمهورية إيران الإسلامية }
\end{aligned}
$$

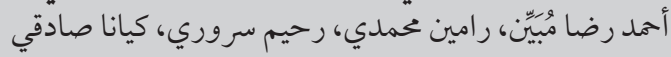

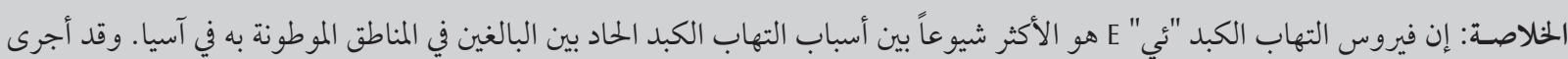

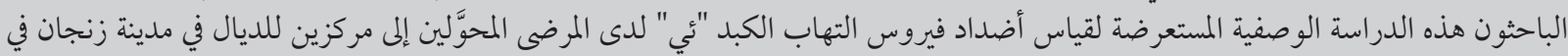

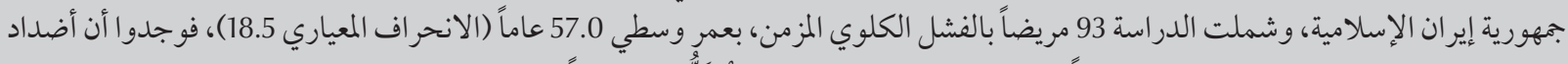

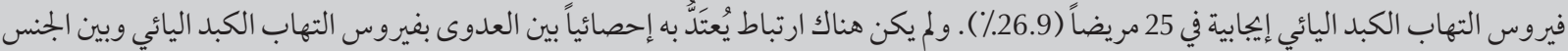

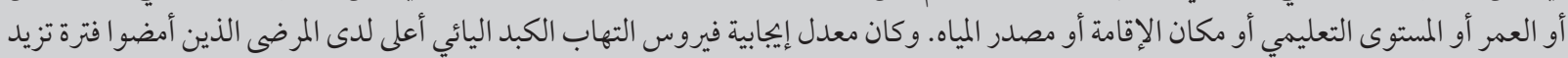

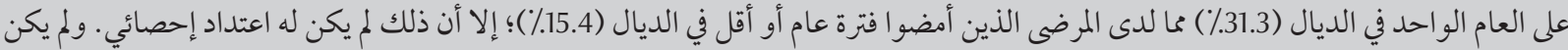

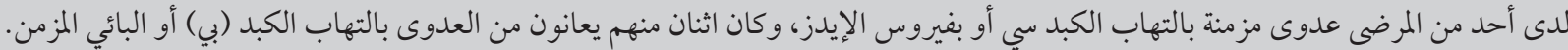

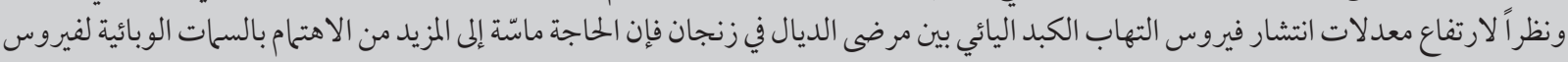

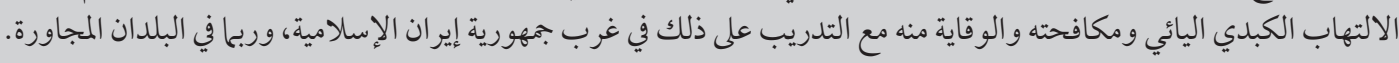

ABSTRACT Hepatitis E virus (HEV) infection is the most common form of acute hepatitis in adults in endemic regions of Asia. In a descriptive, cross-sectional study, anti-HEV antibody was measured in patients referred to the 2 haemodialysis centres in Zanjan city, Islamic Republic of Iran. Among 93 patients with chronic renal failure, mean age 57.0 (SD 18.5) years, antibodies against HEV were positive in 25 (26.9\%) patients. HEV infection was not significantly associated with sex, age, educational level, residence or water source. The rate of HEV positivity was higher in patients with $>1$ than $\leq 1$ year of haemodialysis ( $31.3 \%$ versus $15.4 \%$ ) but this was not statistically significant. None of the patients had chronic hepatitis C or HIV infection, and only 2 were suffering from chronic hepatitis B infection. Given the high prevalence of HEV in haemodialysis patients in Zanjan, more attention is needed towards HEV epidemiology, control, prevention and training in the west of the Islamic Republic of Iran and possibly neighbouring countries.

Séroprévalence du virus de l'hépatite $\mathrm{E}$ chez des patients hémodialysés dans la province de Zanjan (République islamique d'Iran)

RÉSUMÉ L'infection par le virus de l'hépatite E (VHE) représente la forme la plus fréquente de l'hépatite aiguë chez l'adulte dans les régions endémiques d'Asie. Dans une étude descriptive transversale, les anticorps anti-VHE ont été mesurés chez des patients orientés vers deux centres d'hémodialyse de la ville de Zanjan (République islamique d'Iran). Sur 93 patients atteints d'une insuffisance rénale chronique, âgés en moyenne de 57,0 ans (ET 18,5), 25 patients (26,9\%) étaient positifs pour les anticorps anti-VHE. L'infection par le VHE n'était pas significativement associée au sexe, à l'âge, au niveau d'études, au lieu de résidence ni à une source d'eau. Le taux de positivité pour le virus de l'hépatite E était supérieur chez les patients sous hémodialyse depuis plus d'un an, par rapport à ceux traités depuis un an ou moins (31,3\% contre 15,4\%), mais la différence n'était pas statistiquement significative. Aucun des patients n'était infecté par le virus de l'hépatite C chronique ou le VIH, et seulement deux patients souffraient d'une infection chronique par le virus de l'hépatite B. Étant donné la forte prévalence du VHE chez les patients hémodialysés à Zanjan, une attention accrue est requise vis-à-vis de l'épidémiologie du VHE, de la lutte, de la prévention mais aussi de la formation en la matière dans l'ouest de la République islamique d'Iran, voire éventuellement dans les pays voisins.

${ }^{7}$ Department of Infectious Diseases and Tropical Medicine; ${ }^{2}$ Department of Internal Medicine; ${ }^{3}$ Department of Microbiology; ${ }^{4}$ Research Development Centre of Infectious Diseases, Zanjan University of Medical Sciences, Zanjan, Islamic Republic of Iran (Correspondence to A.R. Mobaien:amobaien@yahoo.com).

Received: 22/01/12; accepted: 11/04/12 


\section{Introduction}

Hepatitis $\mathrm{E}$ is a self-limiting acute hepatitis caused by hepatitis E virus (HEV), which can occur both in sporadic or epidemics forms [1]. In terms of clinical symptoms, hepatitis $\mathrm{E}$ cannot be differentiated from other viral hepatitis cases. The spectrum of symptoms ranges from asymptomatic to fulminate disease; most patients suffer from pain, abdominal tenderness, nausea, vomiting and fever. Hepatitis E does not become chronic and often shows no recurrence. The most important complication is a severe fulminate and fetal hepatitis in pregnant women and people with chronic liver disease [2]. While in the industrialized countries, including the United States, HEV is rarely detected, it is the most common form of acute hepatitis in adults in the endemic areas in Asia. The transmission mode of HEV is mainly fecal-oral, and epidemics are typically caused by contamination of water [1]. There is disagreement about other means of viral transmission, and some researchers have maintained that fecal-oral transmission is the only route $[1,2]$. However, recently other means of transmission such as skin contact, blood transfusion [3-5] and mother-to-infant transmission have been proposed [6].

In a number of studies, the seroprevalence of HEV in various community groups have been compared. However, the published results have been inconsistent. While one study rejected a higher HEV seroprevalence in injecting drug users [6], another study supported it $[7,8]$. There have also been contradictory reports concerning haemodialysis patients. While some studies claimed that there were no significant differences between haemodialysis patients and the normal population [9], others reported significant differences [10]. The major causes of these contradictions appear to be due to a lack of matched criteria between selected groups, issues including socioeconomic status, age and so on [11].
Based on several recent studies, while the prevalence of hepatitis $E$ in the Islamic Republic of Iran is lower than in Turkey, it is higher than Saudi Arabia, Pakistan and Iraq $[12,13]$. Because the city of Zanjan is near the endemic hepatitis $E$ areas of the 2 neighbouring countries of Iraq and Turkey, and also due to the limited number of studies related to this disease in dialysis patients in Islamic Republic of Iran [12-20], we decided to analyse the prevalence of anti-HEV antibody $(\mathrm{Ab})$ in a cohort of Iranian haemodialysis patients.

\section{Methods}

\section{Study design and sample}

In this descriptive, cross-sectional study, all the haemodialysis patients referred to Zanjan haemodialysis centres (Valie-Asr and Shahid Beheshti hospitals) in 2011, who were willing to participate, were included on a census basis.

\section{Data collection}

Demographic and clinical variables were recorded using a questionnaire survey designed for that purpose, including age, sex, educational level, residency, source of drinking water and duration and frequency of haemodialysis. Histories of hepatitis $\mathrm{B}(\mathrm{HBV})$ and $\mathrm{C}$ virus (HCV) or human immunodeficiency virus (HIV) infection were extracted from the patient records.

A sample of blood $(3 \mathrm{~mL})$ was taken from each patient, quickly centrifuged and kept at $-70{ }^{\circ} \mathrm{C}$. Following sample collection, the anti-HEV-Ab level was measured by an enzyme-liked immunosorbent assay method by using Bindlaver kit (ELISA, DiaPro, Diagnostic Bioprobes) and the results were recorded on a checklist. All positive samples were tested a second time for conformation.

The study was approved by the ethics committee of Zanjan University of Medical Sciences, and informed consent was obtained from each participant. No intervention outside of routine procedures was done, and there were no additional costs imposed on the participants. Specifications and information about all patients were kept confidential.

\section{Data analysis}

The chi-squared test was performed for statistical analysis using SPSS, version 16. A $P$-value $<0.05$ was considered significant.

\section{Results}

A total of 93 patients [ 49 males (52.7\%) and 44 females (47.3\%)] with chronic renal failure with a mean age of 57.0 (SD 18.5) years (range 16-88 years) who had been admitted to the Zanjan haemodialysis centres (Vali-e-Asr and Shahid Beheshti hospitals) were studied. A summary of the patients' important demographic data including sex, residence, education level and source of drinking water is shown on Table 1.

Antibodies against HEV were positive in 25 (26.9\%) patients and negative in $68(73.1 \%)$. Patients who were antiHEV-Ab positive were slightly more likely to be male, older age, illiterate, living in a village and using unfiltered water. However none of these differences were statistically significant $(P=$ $0.698, P=0.298, P=0.769, P=0.335$ and $P=0.081$ respectively) (Table 1 ).

The mean duration of dialysis in patients who were positive for antiHEV-Ab was 39 months (range 1-24 months) compared with 38 (SD 43) months (range 1-220 months) for anti$\mathrm{HEV}-\mathrm{Ab}$ negative patients. A higher rate of HEV infection was seen in patients who had undergone $>1$ year of haemodialysis (31.3\%) than those who had $\leq$ 1 year of dialysis (15.4\%) but the difference was not statistically significant $(P=$ 0.365) (Table 1). 
Only 2 people were suffering from chronic HBV, 1 of them was positive for anti-HEV-Ab. None of the patients showed evidence of chronic HCV or HIV infection.

\section{Discussion}

Among the 93 participants enrolled in the study, 25 (26.9\%) were found to be positive for anti-HEV-Ab. Only 1 of the patients had chronic HBV in addition to $\mathrm{HEV}$, and none were positive for HCV or HIV. Statistical analysis of the relationship between the variables including sex, age, education, water, residency and history of $\mathrm{HBV}$ infection, showed no significant relationship between these variables and HEV infection. This observation is in line with a
2008 study in the province of Isfahan, reporting no significant difference between the sexes [3].

In several studies conducted on the general population in Islamic Republic of Iran, the prevalence of HEV infection was reported to be between $1.1 \%$ and $30.8 \%$ (Table 2) [12-20]. Only one of these studies, however, was performed on haemodialysis patients: Taremi et al., reporting a 7.4\% HEV infection prevalence in Tabriz [13]. By contrast, our estimate indicated almost a 4 -fold (26.8\%) higher prevalence of HEV infection in haemodialysis patients in Zanjan, a figure that is also much higher than the average estimate for the general population. In line with our results, Rostamzadeh Khameneh et al. reported a high prevalence of HEV infection (30.8\%) among kidney transplant recipients in Urmia, located in the north-west of Islamic Republic of Iran [20]. A possible explanation could be that Zanjan and Urmia are geographically close to the endemic areas of the 2 neighbouring countries to the west of Islamic Republic of Iran, Turkey and Iraq. It is also possible that this high seroprevalence of HEV might be due to infection with an unknown virus, which creates antibodies cross-reacting with HEV [21]. Finally, some studies have proposed blood transfusion as a potential route of HEV transmission, particularly in highly endemic areas $[5,22]$.

Because of a 4-fold higher HEV infection prevalence in Zanjan compared with the normal population of Islamic Republic of Iran, we should pay special attention to the high risk of

\begin{tabular}{|c|c|c|c|c|c|c|}
\hline \multirow[t]{2}{*}{ Variable } & \multirow{2}{*}{$\begin{array}{c}\text { Total } \\
\text { No. }\end{array}$} & \multicolumn{2}{|c|}{ Anti-HEV -ve } & \multicolumn{2}{|c|}{ Anti-HEV +ve } & \multirow[t]{2}{*}{$P$-value ${ }^{a}$} \\
\hline & & No. & $\%$ & No. & $\%$ & \\
\hline Total & 93 & 68 & 73.1 & 25 & 26.9 & \\
\hline \multicolumn{7}{|l|}{ Sex } \\
\hline Male & 49 & 35 & 71.4 & 14 & 28.6 & \multirow{2}{*}{0.698} \\
\hline Female & 44 & 33 & 75.0 & 11 & 25.0 & \\
\hline \multicolumn{7}{|l|}{ Education } \\
\hline Illiterate & 54 & 37 & 68.5 & 17 & 31.5 & \multirow{4}{*}{0.769} \\
\hline Secondary school or lower & 28 & 22 & 78.6 & 6 & 21.4 & \\
\hline Highschool diploma & 4 & 3 & 75.0 & 1 & 25.0 & \\
\hline Bachelor degree or higher & 7 & 6 & 85.7 & 1 & 14.3 & \\
\hline \multicolumn{7}{|l|}{ Age (years) } \\
\hline$<50$ & 31 & 27 & 87.1 & 4 & 12.9 & \multirow{4}{*}{0.298} \\
\hline $50-59$ & 15 & 9 & 60.0 & 6 & 40.0 & \\
\hline $60-69$ & 20 & 13 & 65.0 & 7 & 35.0 & \\
\hline$>70$ & 27 & 19 & 70.4 & 8 & 29.6 & \\
\hline \multicolumn{7}{|l|}{ Location } \\
\hline City & 73 & 54 & 74.0 & 19 & 26.0 & \multirow{2}{*}{0.335} \\
\hline Village & 20 & 14 & 70.0 & 6 & 30.0 & \\
\hline \multicolumn{7}{|l|}{ Drinking water } \\
\hline Filtration & 83 & 63 & 75.9 & 20 & 24.1 & \multirow{2}{*}{0.081} \\
\hline No filtration & 10 & 5 & 50.0 & 5 & 50.0 & \\
\hline \multicolumn{7}{|c|}{ Duration of haemodialysis (years) } \\
\hline$\leq 1$ & 26 & 22 & 84.6 & 4 & 15.4 & \multirow{2}{*}{0.365} \\
\hline$>1$ & 67 & 46 & 68.7 & 21 & 31.3 & \\
\hline
\end{tabular}

${ }^{a}$ Pearson chi-squared test. 


\begin{tabular}{|c|c|c|c|c|}
\hline Study [reference] & Province & Year & Population & $\begin{array}{c}\text { Prevalence } \\
\text { of anti-HEV+ } \\
\%\end{array}$ \\
\hline Aminiafshar $S$ et al. [12] & Tehran & 2004 & Blood donors & 7.8 \\
\hline Safar MJ et al. [14] & Mazandaran & 2005 & General population & 7.2 \\
\hline Taremi M et al. [13] & Tabriz & 2005 & Haemodialysis patients & 7.4 \\
\hline Taremi M et al. [15] & Tabriz & 2007 & Blood donors & 7.8 \\
\hline Ghorbani GA et al. [16] & Tehran & 2007 & General population & 1.1 \\
\hline Ataei B et al. [17] & Isfahan & 2008 & General population & 3.8 \\
\hline Taremi M et al. [18] & Nahavand & 2008 & General population & 9.3 \\
\hline Assarehzadegan MA et al. [19] & Khuzestan & 2008 & Blood donors & 11.5 \\
\hline Rostamzadeh Khameneh Z et al. [20] & Urmia & 2011 & $\begin{array}{l}\text { Renal transplant } \\
\text { recipients }\end{array}$ & 30.8 \\
\hline
\end{tabular}

transmission in this region, as well as the possible means of prevention. Two particular vulnerable groups at risk include pregnant women and those already affected with HBV. Unfortunately, at the moment, HEV vaccines have not been mass produced and are not available for public use [23]. However, if a vaccine became available, $\mathrm{HEV}$ vaccination should be a health priority in areas such as Zanjan.

Our data indicated a tendency towards a higher rate of HEV infection among patients with $>1$ year of haemodialysis versus $\leq 1$ year. It is possible that this is an indication of a rising trend for HEV infection, or that patients who started dialysis in the previous year were somehow more exposed to the risk of infection, or that the risk of infection was simply higher for patients with a longer period of dialysis.

To summarize, the results of our study showed that particular attention should be paid to the problem of HEV epidemiology in the west of Islamic Republic of Iran and possibly in neighbouring countries. We recommend that health officials provide HEV awareness programmes in such areas. Furthermore, because chronic patients may have normal liver enzymes or remain seronegative [24], long-term follow-up of haemodialysis patients seems advisable.

\section{Acknowledgements}

We would like to thank Dr Mehrdad Pedram (Department of Biotechnology and Medical Genetics, Zanjan University of Medical Sciences) for his careful editing of the manuscript and helpful comments.

Funding: This research was supported by a research grant from Zanjan University of Medical Science.

Competing interests: None declared.

\section{References}

1. Anderson DA. Hepatitis E virus. In: Mandell GL, Douglas RG, Bennett JE, eds. Principles and practice of infectious diseases, 7th ed. Philadelphia, Churchill Livingston, 2010:2411-2421.

2. Koff RS. Hepatitis A and E. In: Zakim D, Boyer TD, eds. Hepatology: a textbook of liver disease, 4th ed. Philadelphia, Saunders, 2003:939-958.

3. Arankalle VA, Chobe LP. Hepatitis E virus: can it be transmitted parenterally? Journal of Viral Hepatitis, 1999, 6:161-164.

4. Arankalle VA, Chobe LP. Retrospective analysis of blood transfusion recipients: evidence for post-transfusion hepatitis E. Vox Sanguinis, 2000, 79:72-74.

5. Matsubayashi $\mathrm{K}$ et al. Transfusion-transmitted hepatitis $\mathrm{E}$ caused by apparently indigenous hepatitis $\mathrm{E}$ virus strain in Hokkaido, Japan. Transfusion, 2004, 44:934-940.

6. Krawczynshi K, Aggarwal R. Hepatitis E. In: Schiff ER, Sorrel MF, Maddrey WC, eds. Schiff's disease of the liver, 9th ed. Philadelphia, Lippincott Williams and Wilkins, 2003:880890 .
7. Christensen PB et al. High prevalence of hepatitis E antibodies among Danish prisoners and drug users. Journal of Medical Virology, 2002, 66:49-55.

8. Trinta KS et al. Hepatitis E virus infection in selected Brazilian populations. Memorias do Instituto Oswaldo Cruz, 2001, 96:25-29.

9. Ayoola EA et al. Hepatitis E virus infection in haemodialysis patients: a case-control study in Saudi Arabia. Journal of Medical Virology, 2002, 66:329-334.

10. Lee $\mathrm{CK}$ et al. Prevention of transfusion-transmitted hepatitis $\mathrm{E}$ by donor-initiated self exclusion. Transfusion Medicine, 2005, 15:133-135.

11. Psichogiou M et al. Hepatitis E virus (HEV) infection in haemodialysis patients. The Multicentre Haemodialysis Cohort Study on Viral Hepatitis. Nephrology Dialysis Transplantation, 1996, 11(6):1093-1095.

12. Aminiafshar $\mathrm{S}$ et al. Anti hepatitis $\mathrm{E}$ virus seroposivity in a group of blood donors. Iranian Journal of Public Health, 2004, 33:53-56. 
13. Taremi $\mathrm{M}$ et al. Hepatitis E virus infection in hemodialysis patients: a seroepidemiological survey in Iran. BMC Infectious Diseases, 2005, 5:36.

14. Safar MJ et al. [Seroepidemiology of HEV infection in 2-25 years of saravi in 2004.] Journal of Mazandaran University of Medical Sciences, 2005, 75:82-85 [in Farsi].

15. Taremi $\mathrm{M}$ et al. Prevalence of antibodies to hepatitis $\mathrm{E}$ virus among male blood donors in Tabriz, Islamic Republic of Iran. Eastern Mediterranean Health Journal, 2007, 13:98-102.

16. Ghorbani GA et al. Seroepidemiology of hepatitis E virus in Iranian soldiers. Hepatitis Monthly, 2007, 7:123-126.

17. Ataei B et al. Hepatitis E virus in Isfahan province: a populationbased study. International Journal of Infectious Diseases, 2009, 13:67-71.

18. Taremi M et al. Seroprevalence of hepatitis E in Nahavand, Islamic Republic of Iran: a population-based study. Eastern Mediterranean Health Journal, 2008, 14:157-162.
19. Assarehzadegan MA et al. Seroprevalence of hepatitis E virus in blood donors in Khuzestan Province, southwest Iran. International Journal of Infectious Diseases, 2008, 12:387-390.

20. Rostamzadeh Khameneh Z, Sepehrvand N, Masudi S. Seroprevalence of hepatitis $\mathrm{E}$ among Iranian renal transplant recipients. Hepatitis Monthly, 2011, 11:646-651.

21. Montella F et al. Association between hepatitis E virus and HIV infection in homosexual men. Lancet, 1994, 344:1433.

22. Khuroo MS, Kamili S, Yattoo GN. Hepatitis E virus infection may be transmitted through blood transfusions in an endemic area. Journal of Gastroenterology and Hepatology, 2004, 19:778-784.

23. Aggarwal R, Naik S. Epidemiology of hepatitis E: current status. Journal of Gastroenterology and Hepatology, 2009, 24:1484-1493.

24. Hosseini-Moghaddam SM et al. Hepatitis E virus infection: a general review with a focus on hemodialysis and kidney transplant patients. American Journal of Nephrology, 2010, 31:398-407.

\section{Hepatitis $E$}

The hepatitis E virus is transmitted mainly through the faecal-oral route due to faecal contamination of drinking water.

Other transmission routes have been identified, which include:

- foodborne transmission from ingestion of products derived from infected animals;

- zoonotic transmission from animals to humans;

- transfusion of infected blood products;

- vertical transmission from a pregnant woman to her fetus.

The highest seroprevalence rates of hepatitis E are observed in regions where low standards of sanitation increase the risk for transmission of the virus. Over 60\% of all hepatitis E infections and 65\% of all hepatitis E deaths occur in East and South Asia, where seroprevalence rates of $25 \%$ are common in some age groups. In Egypt, half the population aged above 5 years is serologically positive for the hepatitis E virus.

WHO Fact sheet No. 280

June 2012 